\title{
Multivariate Analyses of Water Quality Dynamics Over Four Decades in the Barataria Basin, Mississippi Delta
}

\author{
John W. Day ${ }^{1}$, Bin Li ${ }^{2}$ D, Brian D. Marx ${ }^{2}$, Dongran Zhao ${ }^{2}$ and Robert R. Lane ${ }^{3, *(D)}$ \\ 1 Department of Oceanography and Coastal Sciences, Louisiana State University, Baton Rouge, \\ LA 70803, USA; johnday@lsu.edu \\ 2 Department of Experimental Statistics, Louisiana State University, Baton Rouge, LA 70803, USA; \\ bli@lsu.edu (B.L.); bmarx@lsu.edu (B.D.M.); dzhao5@lsu.edu (D.Z.) \\ 3 Comite Resources, PO Box 66596, Baton Rouge, LA 70896, USA \\ * Correspondence: rlane@comiteres.com
}

Received: 13 October 2020; Accepted: 5 November 2020; Published: 10 November 2020

check for updates

\begin{abstract}
Here we examine a combined dataset of water quality dynamics in the Barataria Basin, Louisiana based on transect studies from 1977 to 1978 (Seaton) and from 1994 to 2016. The Davis Pond river diversion into Lake Cataouatche began discharging Mississippi River water into the mid-basin in 2005, and so the later dataset was divided in Pre- and Post-diversion periods. The stations from these three datasets (Seaton, Pre- and Post-diversion) were combined into eleven station groupings for statistical analysis that included ANOVA and principal component analysis. In addition, Trophic State Index (TSI) scores were calculated for each grouping during the three time periods. Lake Cataouatche changed the most with the opening of the Davis Pond river diversion, becoming clearer and less eutrophic with addition of river water, which passed through a large wetland area where sediments were retained before entering the lake. The TSI results for the Seaton re-analysis were very similar to the original analysis and to that of the Pre- and Post-diversion datasets, indicating that the trophic status of the basin waters has remained relatively unchanged. The upper-basin has remained eutrophic with degraded water quality while the lower-basin has remained more mesotrophic without significant water quality deterioration. A main cause of water quality deterioration is agricultural runoff and pervasive hydrologic alteration that bypasses wetlands and causes most runoff to flow directly into water bodies.
\end{abstract}

Keywords: river diversion; water quality; principal component analysis; agricultural runoff; denitrification

\section{Introduction}

The Mississippi delta is one of the largest and most productive coastal ecosystems in North America. It is ecologically and economically important, supporting one of the largest fisheries in North America, home to one of the largest port complexes in the world, a major source of oil and natural gas, and the location of extensive petrochemical industries [1]. The delta was formed over the past 7000 years as the river periodically changed course and formed large overlapping deltaic lobes [2-4]. The delta is composed of a number of coastal basins separated by natural levee ridges formed by current and former distributaries of the Mississippi River. Here we address spatial and temporal water quality patterns from the 1970s to the 2016 in the Barataria Basin, which is located between the Mississippi River and Bayou Lafourche, a former distributary of the river (Figure 1).

Human activities have severely degraded environmental conditions in the delta. About $25 \%$ of coastal wetlands were lost in the 20th century due mainly to isolation of most of the delta from 
riverine input by flood control levees and pervasive hydrological alteration of the deltaic plain [5-10]. There has also been widespread water quality deterioration in the delta, with one of the most important factors causing this deterioration being agricultural runoff $[11,12]$. Water quality deterioration due to nutrient enrichment has been reported for the U.S. and many areas worldwide [13-15]. There has been a perverse interaction between hydrological alteration and water quality deterioration in the Barataria Basin and elsewhere in coastal Louisiana. Under natural conditions, most upland runoff from elevated natural levees flowed through wetlands before reaching open water bodies. Now, however, upland runoff, along with drainage from farm fields, is shunted away from developed areas as rapidly as possible by canals and dredged natural channels, often bypassing wetlands to drain directly into open waterbodies, leading to water quality deterioration [16-23].

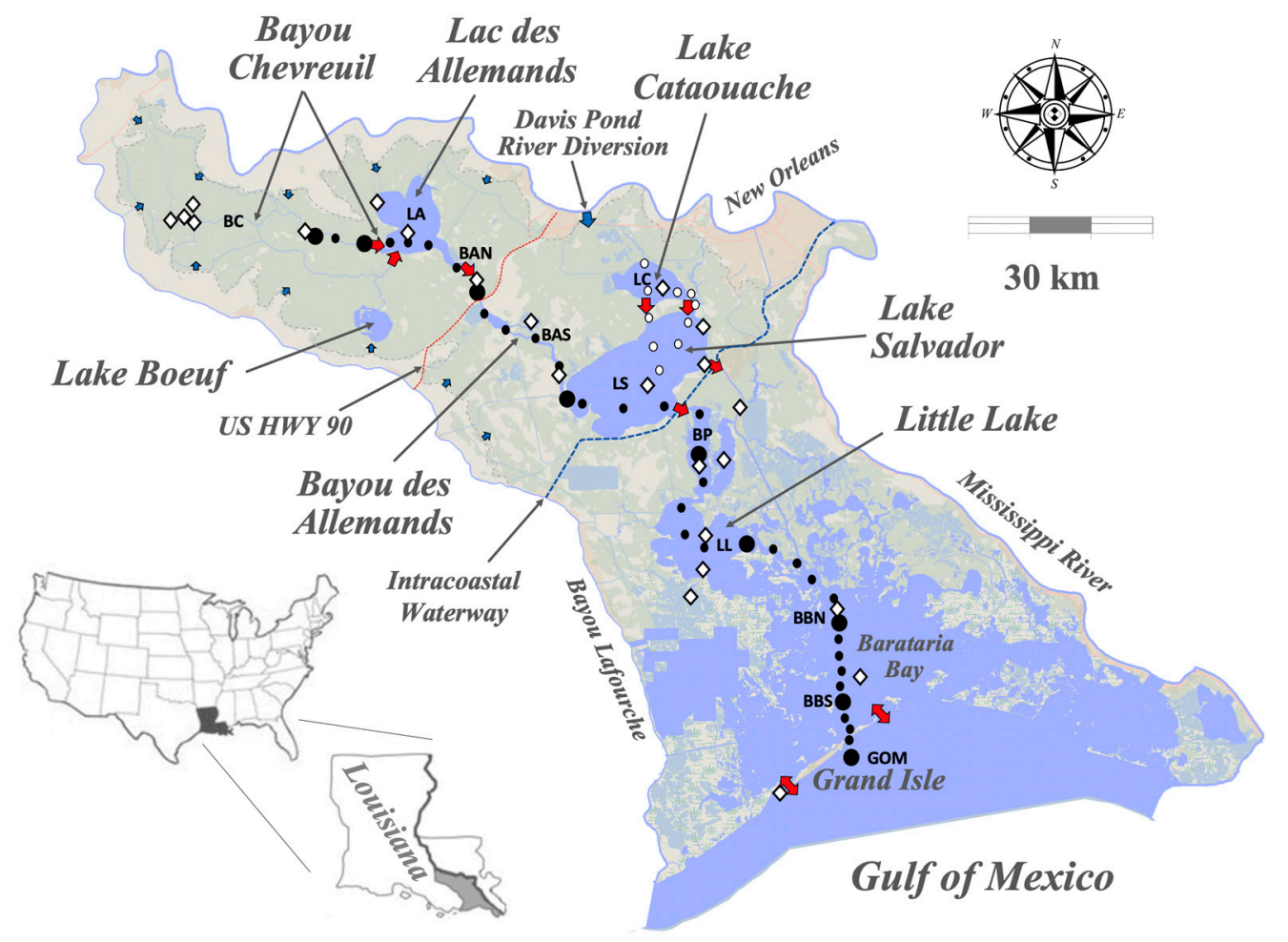

Figure 1. Map showing major features of Barataria Basin (blue-water, green-wetlands, tan-uplands. Symbols represent sampling stations of two transect studies of water parameters in the basin. White diamonds are from [16,24] for 1977-1978 (see Figure S1 in supplemental material). Circles are from [23] for transects from 1995 to 2016 (see Figure S2 in supplemental material). Dark circles are stations along the main drainage axis of the basin (larger circles are every fifth station). White circles are stations added in 2005 to capture the influence of the Davis Pond river diversion, which began operation in 2002. Dark arrows along the periphery of the upper-basin indicate agricultural runoff. Red arrows show the main pathways of water flow in the basin. Bayou des Allemands is the single outlet from the upper-basin (above US HWY 90), and there are two outlets from the mid-basin (between highway 90 and the Intracoastal Waterway) to the lower-basin. Water also flows from Lake Cataouatche to Lake Salvador. Water is exchanged with the Gulf of Mexico through several deep passes. Letters indicate station groupings used for analysis of water quality parameters: BC-Bayou Chevreuil, LA-Lac des Allemands, BAN—Bayou des Allemands north, BAS—Bayou des Allemands south, LS—Lake Salvador, LC_Lake Cataouatche, BP-Bayou Perot, LL-Little Lake, BBN-Barataria Basin north, BBS-Barataria Bay south, and GOM-Gulf of Mexico.

This paper addresses water quality dynamics in the Barataria Basin from the mid-1970s to 2016. We focus on two studies that report on water quality in the basin extending from the freshwater upper-basin to the saline waters of the nearshore Gulf of Mexico [16,23,24]. The objectives of this study 
are to carry out a spatial and temporal analysis of the combined data sets from the two studies, and to use a multivariate approach to compare results of the two transect studies. We hypothesized that:

- water quality is strongly impacted by agricultural runoff in the upper-basin but not in the lower-basin;

- the Davis Pond Mississippi River diversion project impacted water quality in the mid-basin;

- there were strong changes in spatial and temporal patterns of water quality over the past four decades.

\section{Study Area}

The Barataria Basin is a $6600 \mathrm{~km}^{2}$ interdistributary basin located between the natural levees of the Mississippi River and Bayou Lafourche, an abandoned distributary of the Mississippi River that was cut off from the river in 1903 to prevent flooding [7,23] (Figure 1). The aquatic portion of the basin is dominated by forested wetlands in the upper-basin, emergent wetlands in the mid-basin, and open water in the lower-basin adjacent to the Gulf of Mexico. Hydrologically, we divided the area into three sub-basins. The upper-basin is fresh and dominated by cypress swamps and, to a lesser extent by fresh marshes, and is separated from the middle-basin by the embankment of US Highway 90 (US HWY 90). The upper-basin receives the majority of agricultural and urban stormwater runoff entering the basin. Stormwater runoff from uplands surrounding the upper-basin drain into Lac des Allemands via Bayou Chevreuil, which drains the most northwestern portion of the basin, and from Bayou Boeuf, which drains a sub-basin to the south. Water then flows from Lac des Allemands down basin through Bayou des Allemands, which is the only outlet to the mid-basin. The mid-basin is confined between Highway 90 and the Gulf Intracoastal Waterway (GIWW). Water flows from Bayou des Allemands to Lake Salvador and then through two outlets to the lower-basin. Lake Salvador also receives flow from the Lake Cataouatche subbasin, which receives stormwater runoff from the west bank of the New Orleans metropolitan area, and since 2002, Mississippi River water from the Davis Pond river diversion. Wetlands of the mid-basin are mostly fresh to low salinity emergent marshes and small areas of forested wetlands. Water leaving the mid-basin flows through a series of shallow water bodies, including Bayou Perot, Bayou Rigolettes, and Little Lake before entering Barataria Bay. Wetlands of the lower-basin are dominated by brackish and saline marshes, and water is exchanged with the Gulf of Mexico through four deep tidal passes.

The hydrology of the basin is characterized by a low astronomical tide, well-mixed and shallow water depths with long residence times, and a high degree of modification by canals and impact by agricultural runoff. The astronomical tide range is about $30 \mathrm{~cm}$ at the coast but essentially zero in the upper-basin; however, there is longer term water level variability due to factors such as heavy rainfall runoff, frontal passages and seasonal water level changes in the Gulf of Mexico. Water bodies in the basin are shallow ranging from 1 to $3 \mathrm{~m}$ and generally well-mixed and unstratified [25]. Water turnover is one to four times per year in the upper-basin and a just few days in the lower-basin near the tidal inlets $[19,26,27]$. Mississippi River water enters the lower-basin from the Gulf of Mexico during high discharge [23]. Wetland hydrology of the basin has been extensively modified due to canals and water control structures. Additionally, most agricultural runoff is channelized directly into water bodies rather than flowing overland through wetlands, as it did when the system was natural. All of these factors impact the water quality of the basin. Land loss has been low in the upper-basin but is very high in the lower-basin $[5,6,28]$.

Under natural conditions, the basin received regular inputs of river water from crevasses, minor distributaries, and overbank flooding from both the Mississippi River and Bayou Lafourche [2,29,30]. These inputs ceased when Bayou Lafourche was cut off from the Mississippi River in 1903, and with construction of continuous levees along the River after the large 1927 flood, which now prevent annual floodwaters from entering the basin [30]. Minor amounts of river water enter the basin via the GIWW, and since 2002 there is episodic input of river water via the Davis Pond Diversion, which has the capacity to discharge up to about $300 \mathrm{~m}^{3} \mathrm{~s}^{-1}$ of river water. The natural levees along the perimeter of 
Barataria Basin were forested prior to European colonization but have almost all been cleared and converted to agricultural lands, as well as urban and industrial development. There are about 33,850 ha of farm fields above US HWY 90 that drain into the basin, almost all devoted to sugar cane. Agricultural runoff is the major cause of water quality impairment in the upper-basin [12,16-18,23]. Under natural conditions, most runoff from uplands bordering the basin flowed through wetlands as sheet flow or via shallow meandering bayous. The long retention time and interface with wetlands lowered nutrient concentrations of overlying water. Since European colonization, there has been pervasive alteration of wetlands hydrology due to the dredging of canals for stormwater drainage, resulting in runoff with high nutrient concentrations bypassing wetlands and flowing directly into waterbodies [16-22].

\section{Materials and Methods}

This analysis is based on data from two studies that measured a variety of water quality parameters on transects in the Barataria Basin spanning from freshwater forested wetlands in the upper-basin to saline waters of the Gulf of Mexico (Figure 1). The first study from 1977 to 1978 collected samples at 24 stations during eight quarterly transects [16,24]. The second study was much more intensive involving monthly transects over a 23-year period from 1994 to the end of 2016 [23]. The data are available through the Gulf of Mexico Research Initiative Information \& Data Cooperative (GRIIDC at https://data.gulfresearchinitiative.org/data/R4.x264.000:0018). Both studies sampled the central drainage axis of the basin, but there were differences. The Seaton study $[16,24]$ located sampling stations to capture specific characteristics of the basin (agricultural drainage canals, natural swamp and marsh drainage, the GIWW, and Lake Cataouatche, which drains into Lake Salvador), while Turner et al. [23] sampled equidistant stations located approximately $4 \mathrm{~km}$ apart along the central axis of the basin. In 2005, eleven additional stations were added in eastern Lake Salvador and Lake Cataouatche to capture the effects of the Davis Pond diversion, which began operation in 2002. Mississippi River water flowing through the diversion structure was also sampled.

\section{Statistical Methods}

To compare the Seaton, and Pre- and Post-diversion transects, we created station groupings (Figure 1). This was done because Turner et al. sampled a total of 45 stations compared to 24 for Seaton. Moreover, as noted above, Seaton chose a number of stations that were not on the main drainage axis of the basin. A description of the station groupings is provided in the online supplementary material (Table S1).

For each water quality parameter or response, we carried out a two-way analysis of variance (ANOVA) to evaluate the evidence of either an interaction effect or main effect, between two fixed factor variables. We have a 3 by 10 factorial arrangement with the factors being levels of time period (Seaton, Pre-diversion, Post-diversion), each at ten station groupings or locations. Figure 2 depicts the means and standard errors, by station grouping and time period, for each response. Standard assumptions associated with the ANOVA include independence of observations and both normality and homogeneity of variance of the response, conditional on the fixed effects levels. All responses exhibited some features of asymmetry and non-normality, and each was mitigated with a logarithm (base 10) transformation for the analyses. We present our conclusions relative to the natural metric. An interaction occurs when the effect of the time period depends on the level of the station location, or vice-versa. Our data indicated an unbalanced design structure, i.e., the number of observations varied across some factor combinations. As such, the Type-III sums of squares were used for testing and inference. The ANOVA model was performed separately for each response parameter. Any significant interaction further led to pairwise comparisons of the time period effect across each slice of the station location effect. Such post-summaries yielded thirty $(10$ station groups $\times 3$ pairs $=30)$ pairwise comparisons, and we provide both a protected family-wise error rate (Bonferroni) and unprotected (Fisher's least significant difference) at 0.05 level. Our conclusions are based on the strictest significance. 
Less than $1 \%$ of the data were discarded as anomalies, outliers, or missing in these analyses, and the few zeros were also treated as missing.
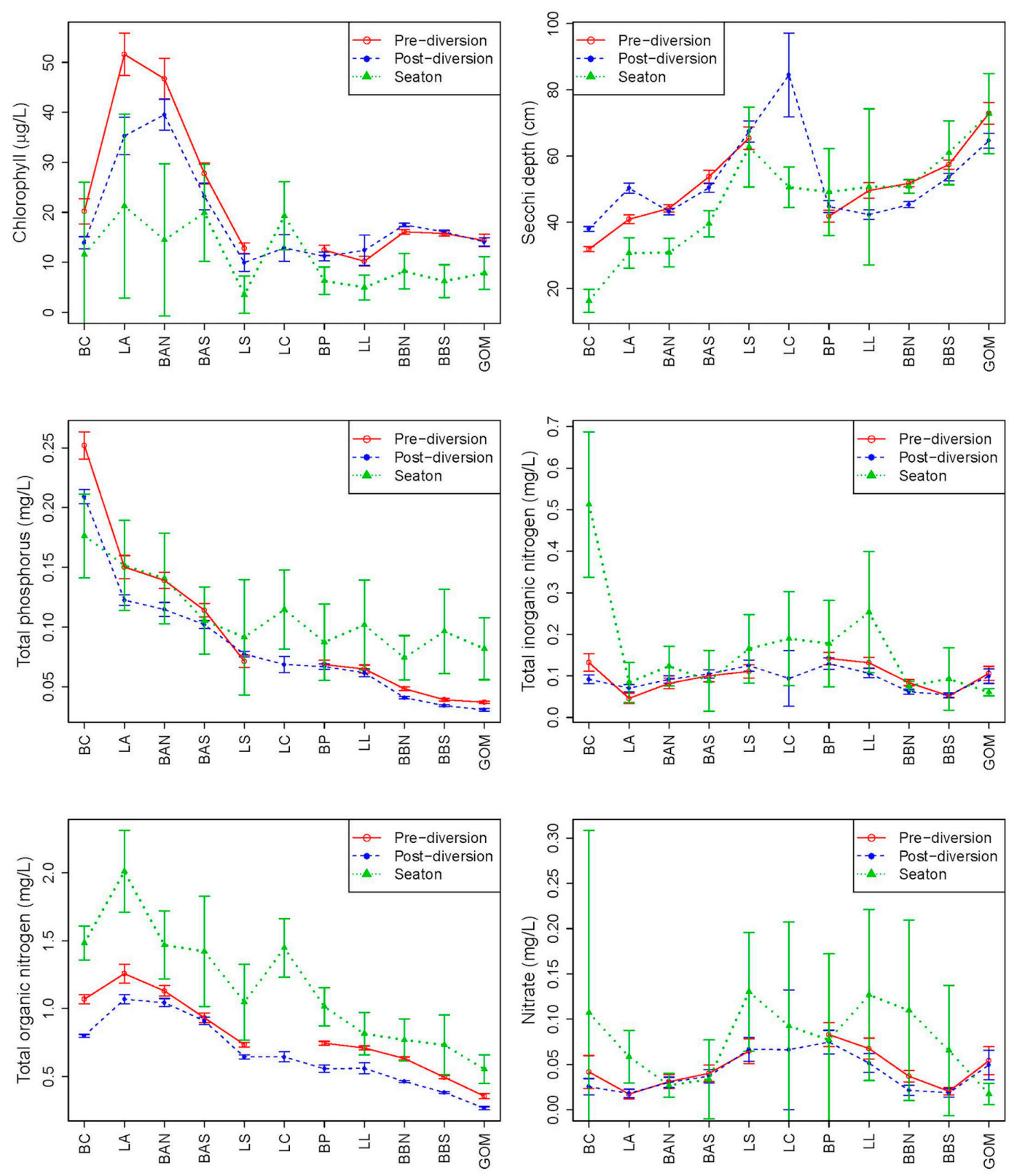

Figure 2. Water quality data from Seaton, Pre- and Post-diversion transects from the upper to lower-basin. The geometric means are provided. The standard error bands are the ones associated with the arithmetic means. Station designations are defined in Figure 1.

Separately, principal component analysis (PCA) is a time-honored and a tried-true dimension reduction and data visualization tool, was also used on this data. The principal components (PC), which are linear combinations of variables, provide the best low-dimensional approximation of the data in terms of the variance. The loading vector, the coefficients for the linear combination of variables, shows the contribution of each of the variables in the corresponding PC. Since the leading few PCs can often explain most of the variance among the samples, we can visualize the high-dimensional data using the first few PC scores.

$\mathrm{K}$-means clustering is the oldest and one of the most popular clustering methods. Given the number of clusters (i.e., k), the k-means clustering algorithm minimizes the within-cluster sum of 
squares through an iterative process. The average silhouette width, which measures the quality of a clustering (i.e., how close each object lies within its own cluster and how far it is to the objects that lie in other clusters), is used to determine the optimal number of clusters. The average silhouette method computes the average width for the observations across different values of $\mathrm{k}$. The optimal number of clusters is the one that maximizes the average silhouette over a range of possible values for $\mathrm{k}$. A high average silhouette width indicates a good clustering [31].

We calculated Trophic State Index (TSI) scores for the Seaton and Pre-transect and Post-transect data sets. Ref. [16,24] based the development of the Barataria Basin TSI on the work of [32], who used a multivariate analysis to characterize the trophic state of 55 Florida lakes. Our analysis followed this approach, where we re-analyzed the Seaton data as well as Pre- and Post-diversion data from [23]. The TSI for the Barataria Basin was calculated using the first PC score from four trophic state indicators: Total Organic Nitrogen (TON), Total Phosphorus (TP), Secchi Depth (SD), and Chlorophyll $a$ (CHL). Specifically, the TSI scores were calculated using the first PC on 4 (SD, CHL, TON, TP) variables for Pre-, Post-diversion and Seaton data sets, separately. The PCA was done on the correlation matrix (i.e., all variables were standardized to have zero mean and unit variance). Note that TSI scores are unitless, and any interpretation should be solely based on their signs and magnitudes relative to each other.

\section{Results}

The two-way ANOVA model with interaction was fit, and the interaction between station and time period was highly significant for every response ( $p<<0.001$ for CHL, SD, TP, TIN and TON, and $p<0.01$ for Nitrate). This indicates that the main effect for time period varied over the station location, as illustrated in Figure 2, a feature that we will further discuss below, along with the summary in Table S2 (see supplementary online material). With such strong interaction effects, we refrain from over-interpreting the main effects, as masking or a more complex effect structure exists. However, it should be noted that in all cases the main effect for location was highly significant $(p<0.0001)$, indicating strong spatial variation in the responses across stations. All of the pairwise comparison statements below have a Bonferroni family-wise protection at 0.05 for each response and are reflective of differences found within Figure 2. Since we imposed the logarithmic transformation for the ANOVA on the water quality responses, Figure 2 displays the geometric means. As geometric means have unitless standard errors, the associated standard error bars provided in Figure 2 are those of the arithmetic means.

Mean chlorophyll $a$ concentrations generally ranged from $>20$ to $\sim 70 \mu \mathrm{g} / \mathrm{L}$ in the upper-basin, which is strongly influenced by upland runoff, and decreased to $<20 \mu \mathrm{g} / \mathrm{L}$ in the mid- and lower-basin. Chlorophyll $a$ levels were significantly higher in the upper-basin, with Lake des Allemands (LA), Bayou des Allemands north (BAN) and south (BAS) significantly higher than the other stations down basin and Bayou Chevreuil (BC) up basin $(p<0.05$, protected). The decrease at BC was most likely due to light limitation due to high turbidity and shading from trees. Chlorophyll $a$ was significantly higher during the Pre- and Post-transects compared to Seaton for stations BAN and Lake Salvador (LS), as well for all of the stations in the lower-basin. Although chlorophyll $a$ concentrations were higher in Lake Cataouatche (LC) during the Seaton transects compared to Post-diversion, the difference was not significant.

Turbidity was significantly higher in the upper-basin, as reflected by low Secchi depth values, and water clarity increased down basin. Although the main effect trend of clarity was highly significant and apparently linear along the distance gradient, most of the mean Secchi depth differences that were found across the time periods were in the upper-basin. Specifically, for Bayou Chevreuil (BC), a significant ranking for Secchi depth was found (in decreasing order): Post-diversion, Pre-diversion, and finally Seaton. Pre- and Post-diversion Secchi depths were significantly greater than Seaton in the upper-basin, and Post-diversion Secchi depths were greater than Pre-diversion at LA, Little Lake (LL), and Barataria Basin north (BBN). Post-diversion mean Secchi depth was significantly greater than 
that found by Seaton in LC ( $p<0.05$, protected). All of these trends suggest increased water clarity over time.

Nitrate concentrations were generally less than $0.3 \mathrm{mg} / \mathrm{L}$ and, with the exception of station Bayou Chevreuil (BC), there were no significant differences between stations or transects. There was a spatial trend of higher concentrations at $\mathrm{BC}$ compared to Lac des Allemands (LA), and then increasing concentrations peaking in the mid-basin, and then decreasing to the Gulf of Mexico (GOM). Total inorganic nitrogen had a similar spatial pattern as nitrate.

Opposite to what was observed for nitrate and inorganic nitrogen, total organic nitrogen was lower in BC compared to LA. After LA, there was a significant decreasing trend for stations approaching the GOM ( $p<0.05$, protected). Overall, total organic nitrogen was significantly higher during the Seaton transects compared to the Pre- and Post-diversion transects at most stations, including Lake Cataouatche (LC; $p<0.05$, protected).

Total phosphorus concentrations ranged from $\sim 0.2$ to $0.3 \mathrm{mg} / \mathrm{L}$ at BC and generally decreased down basin. Total phosphorus was significantly higher for the Seaton transect in the lower-basin, with significantly higher mean TP concentrations compared to both Pre- and Post-diversion transects, especially at Barataria Bay south (BBS) and GOM ( $p<0.05$, protected). There were significantly higher mean phosphorus values during the Pre-diversion transects relative to Post-diversion, and no differences to compared to Seaton. There were highly significant differences for total phosphorus in the upper-basin (BC, LA, and BAN; $p<0.05$, protected).

We aimed to understand how the station locations are hydrologically connected, within each time period. To achieve this, objectively and visually, we first clustered stations that were similar to each other and plotted these clusters onto the primary principal components of the water quality variables. Figure 3 (left panels) shows the k-means clustering results by projecting the stations onto the first two principal components (PCs). Each point in the plots represents a station. Different colors and symbols are used to separate the samples from different clusters. The number of clusters for each plot was chosen to maximize the average silhouette width. The percentages within the parenthesis are the proportion of total variance explained by the corresponding PC. The first two PCs explain over $80 \%$ of the total variance in all three cases. In the Seaton data, the optimal number of clusters is three, which is less than the Pre- and Post-diversion cases. This is probably due to the small sample size for the Seaton data as compared to those for Pre- and Post-diversion. Thus, these biplots give a good impression of the actual clustering. Note that the optimal numbers of clusters for Pre-diversion and Post-diversion data are nine and seven, respectively. In order to have a reasonable and fair comparison, we choose eight clusters for both of these cases. The average silhouette width for eight clusters is very close to its maximum value in both cases. The Pre-diversion, Post-diversion, and Seaton clustering show goodness of fit. The ratio between between-cluster variation and total variation, which is similar to the R-square in regression, is $93.5 \%, 92.1 \%$, and $68.9 \%$, respectively. Values closer to $100 \%$ yield better separation.

The means of the station groupings yield a number of interesting spatial and temporal patterns among Seaton, Pre-diversion, and Post-diversion transects. All three time periods show an enriched upper-basin with turbid waters, high nutrients and chlorophyll $a$ levels. In contrast, lower-basin stations generally have clearer water, lower nutrients, and lower chlorophyll $a$. In the bayou stations draining into Lac des Allemands, chlorophyll $a$ is lower and nutrients are higher and water is somewhat more turbid. However, it is likely that light limitation, due both to high turbidity levels and shading by swamp forests lining the narrow bayous are the main factors leading to lower phytoplankton biomass. Stations downstream of Lake Salvador generally have low chlorophyll $a$ and nutrient levels and greater water clarity although there seems to be minor enrichment after the opening of the Davis Pond diversion but this was not significant.

When clusters were displayed on maps of the basin with sampling stations included, clustering shows strong spatial patterns (Figure 3 right). The arrows in Figure 3 (right panels) show how clusters are connected hydrologically and reflect water flow in the basin. The clusters separated clearly from 
upper- to lower-basin. This finding reflects water flowing down basin from highly enriched water of the upper-basin to cleaner water of the lower-basin. When these spatial patterns are combined with water flow patterns, it is clear that the clusters reflect both the hydrologic connectivity of the basin from fresh to saline as well and biogeochemical processing of nutrients as water flows down basin.
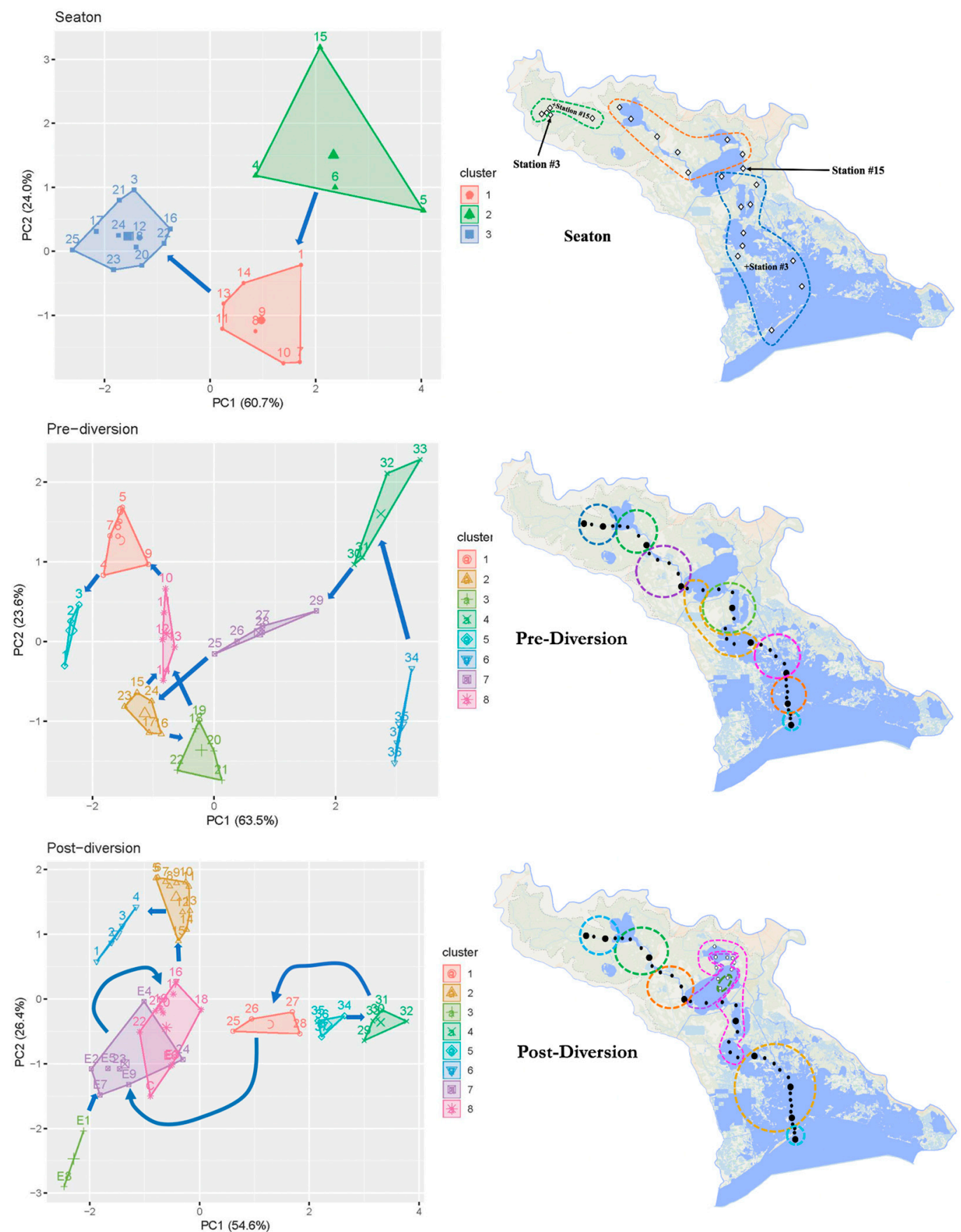

Figure 3. The k-means clustering of stations, across the three time periods: Seaton, Pre-diversion and Post-diversion. Arrows show how the clusters are hydrologically connected. Clusters for each case are shown on maps of the basin with sampling stations. Top row Seaton, middle row Pre-diversion, bottom row Post-diversion. These figures show that the statistical analysis captures both hydrological flow as well as nutrient biogeochemistry.

Lake Cataouatche is the area that has changed the most with the opening of the Davis Pond river diversion. When the Seaton transects occurred, Lake Cataouatche received considerable agricultural 
and urban runoff. The lake was turbid with relatively high nutrient and chlorophyll $a$ levels similar to the upper-basin. With the opening of the Davis Pond diversion, the Mississippi River became the main source of freshwater to the lake. Diverted river water first flows through a large wetland receiving basin where most river sediments settle so the water flowing into the lake is relatively clear. In addition, dense submerged aquatic vegetation beds promote sediment settling and inhibit resuspension. The mean Post-diversion Secchi disk depth was $>100 \mathrm{~cm}$, the clearest water in the basin. Nitrate was the main inorganic nitrogen form with a mean concentration $<0.2 \mathrm{mg} / \mathrm{L}$ compared to $1-2 \mathrm{mg} / \mathrm{L}$ in the river. Nitrate is rapidly reduced by denitrification and plant uptake in the Davis Pond wetlands and shallow submerged sediments of the lake [33,34]. The turnover time of the lake prior to the Davis Pond diversion was 1-2 months, but when the diversion is running, it is capable of replacing the entire volume of Lake Cataouatche in three days [35]. Thus, phytoplankton growth is likely limited both by low inorganic $\mathrm{N}$ and rapid flushing time.

From Figure 3 and Tables 1 and 2, we make the following observations:

(a). CHL, TON, and TP are positively correlated. SD is negatively correlated with the other four variables. TIN is weakly correlated with CHL, TON, and TP. See Table 1.

(b). The first principal component (PC1) in all three cases mainly reflects the difference between SD and the sum of CHL, TON, and TP. See Table 2.

(c). TIN is the most influential factor in second principal component (PC2) for all three cases. See Table 2.

(d). For the Seaton case, cluster 1 and cluster 2 samples have positive PC1 scores (implying high SD and low CHL, TON, and TP values), while cluster 3 samples have negative PC1 scores (implying low SD and high CHL, TON, and TP values). See Figure 3.

(e). Cluster 2 samples have positive PC2 scores (implying high TIN), while cluster 1 samples have negative PC2 scores (implies low TIN). See Figure 3.

(f). For pre- and post-diversion cases, cluster 4 and 6 in pre-diversion correspond to cluster 4 and 5 in post-diversion. Both clusters have the largest PC1 scores, which implies high SD and low CHL, TON, and TP values.

(g). The PC2 loadings for TIN in pre- and post-diversions have opposite signs. The top cluster in pre-diversion implies low values in TIN, while the top ones in post-diversion implies high TIN values.

Table 1. Correlation matrices of response variables, from Turner and Seaton data. The water quality response abbreviations are defined in Section 3.

\begin{tabular}{cccccc}
\hline Variable & SD & CHL & TON & TP & TIN \\
\hline SD & & $-0.21(-0.17)$ & $-0.17(-0.26)$ & $-0.15(-0.05)$ & $-0.24(-0.28)$ \\
CHL & $-0.21(-0.17)$ & & $0.79(0.38)$ & $0.35(0.21)$ & $-0.15(0.20)$ \\
TON & $-0.17(-0.26)$ & $0.79(0.38)$ & & $0.47(0.27)$ & $-0.09(0.21)$ \\
TP & $-0.15(-0.05)$ & $0.35(0.21)$ & $0.47(0.27)$ & & $0.07(0.11)$ \\
TIN & $-0.24(-0.28)$ & $-0.15(0.20)$ & $-0.09(0.21)$ & $0.07(0.11)$ & \\
\hline
\end{tabular}

Table 2. The loading vectors for principal component (PC) 1 and PC2 for Pre-, Post-diversion and Seaton data.

\begin{tabular}{ccccccc}
\hline Variable & PC1 (Pre) & PC2 (Pre) & PC1 (Post) & PC2 (Post) & PC1 (Seaton) & PC2 (Seaton) \\
\hline SD & 0.473 & 0.078 & 0.383 & 0.491 & 0.509 & 0.000 \\
CHL & -0.464 & 0.431 & -0.546 & 0.038 & -0.437 & -0.505 \\
TON & -0.536 & 0.022 & -0.520 & 0.389 & -0.464 & -0.426 \\
TP & -0.514 & -0.176 & -0.456 & 0.348 & -0.445 & 0.432 \\
TIN & -0.091 & -0.886 & 0.278 & 0.697 & -0.368 & 0.615 \\
\hline
\end{tabular}


The TSI scores for the Seaton, Pre-diversion, and Post-diversion transects yielded very similar spatial patterns, with eutrophic conditions (positive) in the northern basin and mesotrophic (negative) in the lower basin (Figure 4; Table 3). Scores for stations upstream of Lake Salvador (LS) were generally greater than one. The highest scores were for Bayou des Allemands north (BAN), Lac des Allemands (LA), and bayous receiving agricultural runoff (LA, BAN, and LC). These stations had high nutrients, chlorophyll $a$ and turbidity with low Secchi disk depths (see Figure 2). Downstream of Lake Salvador, TSI scores for the three periods were generally less than -1 , indicating more mesotrophic waters with greater clarity and lower chlorophyll $a$ and nutrient levels (BP, LL, BBN, BBS and GOM). Post-diversion scores in this lower region were somewhat elevated compared to Pre-diversion scores, suggesting a slight tendency towards more enrichment. Lake Cataouatche (LC) scored greater than zero for the Seaton transects while the Post-diversion score was about -1 . As noted above, the shift was likely due to relatively clearer river water (after sediments had dropped out) entering the lake, the sediments having been retained in the Davis Pond wetlands as well as rapid reduction of $\mathrm{NO}_{3}$ due to high denitrification rates.

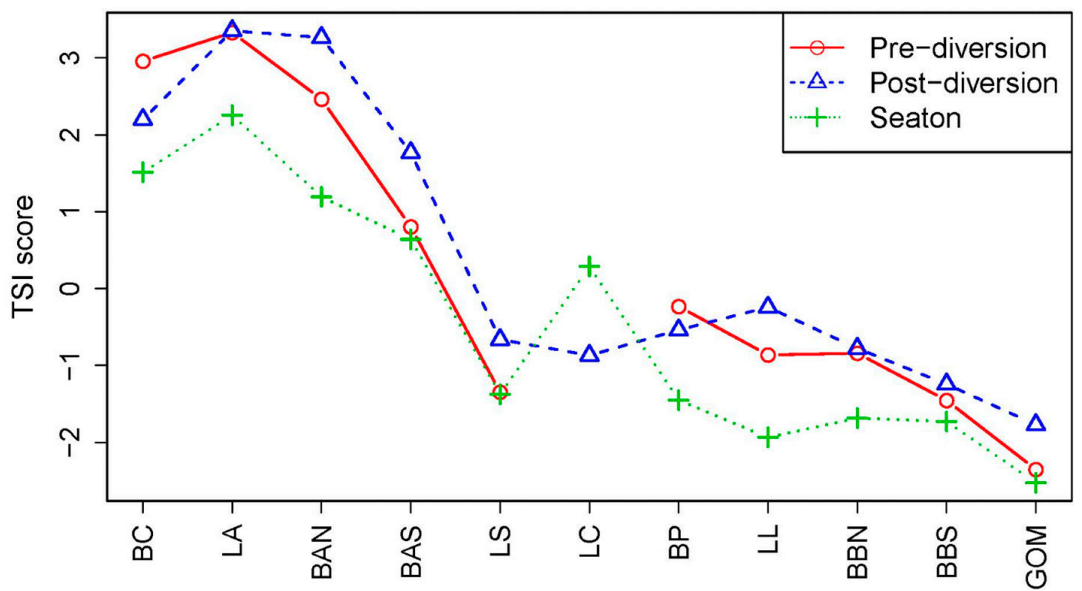

Figure 4. Trophic State Index scores for station groupings for the Seaton, Pre-diversion and Post-diversion transects for 4-variable analysis.

Table 3. Trophic State Index (TSI) scores for 4-variables and 5-variables data.

\begin{tabular}{cccccccc}
\hline $\begin{array}{c}\text { Turner } \\
\text { Station }\end{array}$ & $\begin{array}{c}\text { 4-var and } \\
\text { Pre }\end{array}$ & $\begin{array}{c}\text { 4-var and } \\
\text { Post }\end{array}$ & $\begin{array}{c}\text { 5-var and } \\
\text { Pre }\end{array}$ & $\begin{array}{c}\text { 5-var and } \\
\text { Post }\end{array}$ & $\begin{array}{c}\text { Seaton } \\
\text { Station }\end{array}$ & $\begin{array}{c}\text { 4-var } \\
\text { Seaton }\end{array}$ & $\begin{array}{c}\text { 5-var } \\
\text { Seaton }\end{array}$ \\
\hline BT01 & -2.49 & -1.95 & -2.46 & -1.95 & 1 & 1.95 & 1.83 \\
BT02 & -2.35 & -1.77 & -2.37 & -1.77 & 3 & -1.48 & -1.44 \\
BT03 & -2.19 & -1.70 & -2.23 & -1.70 & 4 & 0.38 & 0.89 \\
BT04 & -1.76 & -1.54 & -1.85 & -1.54 & 5 & 3.03 & 3.91 \\
BT05 & -1.35 & -1.34 & -1.52 & -1.34 & 6 & 2.64 & 2.92 \\
BT06 & -1.41 & -1.33 & -1.57 & -1.33 & 7 & 2.25 & 1.77 \\
BT07 & -1.60 & -1.20 & -1.73 & -1.20 & 8 & 1.31 & 0.99 \\
BT08 & -1.46 & -1.10 & -1.60 & -1.10 & 9 & 1.19 & 0.86 \\
BT09 & -0.99 & -0.94 & -1.09 & -0.94 & 10 & 1.7 & 1.27 \\
BT10 & -0.73 & -0.78 & -0.81 & -0.78 & 11 & 0.64 & 0.29 \\
BT11 & -0.79 & -0.70 & -0.84 & -0.70 & 12 & -1.38 & -1.39 \\
BT12 & -0.85 & -0.69 & -0.86 & -0.69 & 13 & 0.29 & 0.14 \\
BT13 & -0.66 & -0.55 & -0.66 & -0.55 & 14 & 0.8 & 0.69 \\
BT14 & -0.89 & -0.53 & -0.85 & -0.53 & 15 & 1.12 & 2.11 \\
BT15 & -1.34 & -0.62 & -1.29 & -0.62 & 16 & -0.96 & -0.82 \\
BT16 & -0.98 & -0.45 & -0.89 & -0.45 & 17 & -2.34 & -2.23 \\
BT17 & -1.19 & -0.43 & -1.09 & -0.43 & 18 & -1.45 & -1.46 \\
BT18 & -0.42 & 0.15 & -0.32 & 0.15 & 20 & -1.15 & -1.36 \\
BT19 & -0.34 & -0.59 & -0.26 & -0.59 & 21 & -1.94 & -1.73 \\
\hline
\end{tabular}


Table 3. Cont

\begin{tabular}{cccccccc}
\hline $\begin{array}{c}\text { Turner } \\
\text { Station }\end{array}$ & $\begin{array}{c}\text { 4-var and } \\
\text { Pre }\end{array}$ & $\begin{array}{c}\text { 4-var and } \\
\text { Post }\end{array}$ & $\begin{array}{c}\text { 5-var and } \\
\text { Pre }\end{array}$ & $\begin{array}{c}\text { 5-var and } \\
\text { Post }\end{array}$ & $\begin{array}{c}\text { Seaton } \\
\text { Station }\end{array}$ & $\begin{array}{c}\text { 4-var } \\
\text { Seaton }\end{array}$ & $\begin{array}{c}\text { 5-var } \\
\text { Seaton }\end{array}$ \\
\hline BT20 & -0.13 & -0.49 & -0.01 & -0.49 & 22 & -0.67 & -0.85 \\
BT21 & -0.03 & -0.61 & 0.12 & -0.61 & 23 & -1.68 & -1.9 \\
BT22 & -0.76 & -0.87 & -0.62 & -0.87 & 24 & -1.73 & -1.8 \\
BT23 & -1.58 & -1.20 & -1.50 & -1.20 & 25 & -2.53 & -2.69 \\
BT24 & -1.12 & -0.13 & -1.04 & -0.13 & & & \\
BT25 & -0.01 & 0.66 & 0.01 & 0.66 & & \\
BT26 & 0.37 & 0.95 & 0.38 & 0.95 & & \\
BT27 & 0.81 & 1.65 & 0.81 & 1.65 & & \\
BT28 & 0.79 & 1.89 & 0.80 & 1.89 & & \\
BT29 & 1.72 & 3.01 & 1.71 & 3.01 & & \\
BT30 & 2.40 & 3.21 & 2.34 & 3.21 & & \\
BT31 & 2.53 & 3.32 & 2.48 & 3.32 & & \\
BT32 & 3.04 & 3.69 & 2.89 & 3.69 & & \\
BT33 & 3.62 & 3.02 & 3.45 & 3.02 & & \\
BT34 & 3.27 & 2.56 & 3.30 & 2.56 & & \\
BT35 & 3.04 & 2.12 & 3.12 & 2.12 & & \\
BT36 & 2.88 & 2.22 & 3.00 & 2.22 & & \\
BT37 & 2.95 & 2.25 & 3.05 & 2.25 & & \\
EM01 & NA & -1.60 & NA & -1.60 & & \\
EM02 & NA & -1.65 & NA & -1.65 & & \\
EM03 & NA & -0.07 & NA & -0.07 & & \\
EM04 & NA & -0.60 & NA & -0.60 & & \\
EM05 & NA & -1.14 & NA & -1.14 & & \\
EM06 & NA & -0.11 & NA & -0.11 & & \\
EM07 & NA & -1.45 & NA & -1.45 & & \\
EM08 & NA & -1.77 & NA & -1.77 & & \\
EM09 & NA & -1.09 & NA & -1.09 & & \\
CUT1 & NA & 0.29 & NA & 0.29 & & \\
\hline
\end{tabular}

The TSI results for the Seaton re-analysis were very similar to the original analysis. The analysis for the Pre- and Post-diversion data sets yielded results that were very similar to the Seaton re-analysis. This indicates that the trophic status of the basin waters has remained relatively unchanged over the period of the two studies. Upper-basin stations are in the eutrophic to hyper-eutrophic range while Lake Salvador and lower-basin stations are mesotrophic. It is interesting to note that Lake Cataouatche was eutrophic for the Seaton study, but was mesotrophic for the Post-diversion transects. This reflects clear water due to river sediments being deposited in the Davis Pond outfall area, the rapid reduction in $\mathrm{NO}_{3}$ most likely due to denitrification and plant uptake, and the rapid flushing of the lake.

\section{Discussion}

In general, our analysis shows that water quality patterns in the Barataria Basin were similar for the Seaton transects in the 1970s and Pre- and Post-diversion measurements from 1995 to 2016. The upper-basin remained eutrophic with degraded water quality throughout the study period while the lower-basin was more mesotrophic without significant water quality deterioration. The opening of the Davis Pond diversion actually led to improved water quality in Lake Cataouatche. The impact of the diversion was reflected at stations between Lake Salvador and Barataria Bay indicating a slight tendency to more enrichment.

\section{Wetland-Nutrient Interactions in the Upper Barataria Basin}

Neither the Seaton, Pre- or Post-diversion transects detected the water quality signal (i.e., high nitrate and TSS) from agricultural drainage. Water chemistry data were from transects along the central drainage axis of the basin during calm weather and generally showed low levels of nitrate and other 
nutrients compared to agricultural runoff. For the Seaton transects, only four stations had $\mathrm{NO}_{3}$ values greater than $1 \mathrm{mg} / \mathrm{L}$; there were three samples between 1 and $2 \mathrm{mg} / \mathrm{L}$ and one value of $3 \mathrm{mg} / \mathrm{L}$. For the Pre- and Post-diversion transects, the highest $\mathrm{NO}_{3}$ sampled was $2.5 \mathrm{mg} / \mathrm{L}$, and there were only three samples higher than $2 \mathrm{mg} / \mathrm{L}$. By contrast, $\mathrm{NO}_{3}$ resulting from agricultural runoff is regularly greater than $5 \mathrm{mg} / \mathrm{L}$ and was as high as $13 \mathrm{mg} / \mathrm{L}$ [12].

In order to capture the effects of episodic rainfall events on agricultural drainage water quality, [12] (see also [36]) sampled during rainfall events in channels draining sugarcane fields, a dredged canal receiving direct runoff from sugarcane fields, a natural bayou receiving agricultural runoff (St. James Canal and Bayou Chevreuil), and drainage from a natural swamp forest. Mean concentrations of nutrients and total suspended sediments (TSS) were uniformly low in drainage from the natural swamp (nitrate $0.2-0.3 \mathrm{mg} / \mathrm{L}$, ammonia $0.1 \mathrm{mg} / \mathrm{L}$, Total Kjeldahl N $1.4 \mathrm{mg} / \mathrm{L}, \mathrm{TP} 0.0-0.4 \mathrm{mg} / \mathrm{L}$, phosphate $0.1-0.2 \mathrm{mg} / \mathrm{L}$, TSS $24-29 \mathrm{mg} / \mathrm{L})$. By contrast, concentrations were much higher in water ways directly receiving agricultural runoff $\left(\mathrm{NO}_{3} 0.5-2.7 \mathrm{mg} / \mathrm{L}, \mathrm{NH}_{4} 0.1-0.4 \mathrm{mg} / \mathrm{L}, \mathrm{TKN} 1.9-2.2 \mathrm{mg} / \mathrm{L}, \mathrm{TP}\right.$ 0.0-0.4 mg/L, $\mathrm{PO}_{4} 0.1-0.2 \mathrm{mg} / \mathrm{L}$, TSS $61-275 \mathrm{mg} / \mathrm{L}$ ). TSS and nutrient levels were much higher in agricultural runoff following high rainfall events, with TSS ranging from 400 to $2600 \mathrm{mg} / \mathrm{L}$, and nutrients concentrations of $0.8-3.0 \mathrm{mg} / \mathrm{L}$ for TP, $<1-13 \mathrm{mg} / \mathrm{L}$ for $\mathrm{NO}_{3}, 2-17 \mathrm{mg} / \mathrm{L}$ for TKN, and $0.8-3.2 \mathrm{mg} / \mathrm{L}$ for TP.

A series of studies of the forested wetlands adjacent to Bayou Chevreuil demonstrate the relative stability and insensitivity of nutrient concentrations in drainage from natural swamps [12]. Ref. [24] reported that the inorganic N:P ratio of water draining from the swamp always averaged $\sim 2$ and was not affected by the weighted 5-day precipitation average prior to sampling. By contrast, the N:P ratio in Bayou Chevreuil was significantly and positively related to the 5-day weighted precipitation average. At rainfall levels averaging greater than $2 \mathrm{~cm}$ in 5 days, the N:P ratio was $>20$ indicating strong $\mathrm{P}$ limitation. With no rainfall the previous 5 days, the N:P ratio was $<5$ and was not much different from the natural swamp drainage. Since this swamp receives agricultural runoff, it shows that the wetland reduces nutrient concentrations, especially nitrate. Ref. [24] sampled and modeled nutrients in water as it flowed through the swamp and reported strong uptake of $\mathrm{NO}_{3}(87 \%)$ and $\mathrm{NH}_{4}(33 \%)$ and release of $\mathrm{PO}_{4}$, organic $\mathrm{N}$ and organic $\mathrm{P}$, indicating the swamp was removing and transforming inorganic floodwater nutrient concentrations. Ref. [22] characterized the impact of agricultural drainage on surface water quality in the Bayou Boeuf Basin. Nitrate was generally lower than $0.1 \mathrm{mg} / \mathrm{L}$ except during high runoff periods when concentrations reached $1-3 \mathrm{mg} / \mathrm{L}$. TN was comprised mostly of organic nitrogen. TSS levels were generally below $30-40 \mathrm{mg} / \mathrm{L}$ except during runoff events when levels exceeded $100 \mathrm{mg} / \mathrm{L}$.

The result of these studies $[12,22,24]$ indicated that the deterioration of water quality in the upper-basin above the GIWW was due to the combination of (1) agricultural runoff with high nutrients and (2) canals that allowed runoff to bypass wetlands and flow directly into open water bodies. Inorganic nutrients in agricultural drainage, especially $\mathrm{NO}_{3}$, were rapidly reduced, especially where water flows through wetlands and over submerged sediments.

The research by [34] reviewed studies of denitrification in coastal Louisiana including the Barataria Basin. Submerged sediments and wetland soils wetlands are capable of high denitrification rates when exposed to high $\mathrm{NO}_{3}$ concentrations $(>100 \mu \mathrm{M}=1.4 \mathrm{mg} / \mathrm{L})$. Maximum potential denitrification can reach values $>2500 \mu \mathrm{mol} \mathrm{m}^{-2} \mathrm{~h}^{-1}$. In the Barataria Basin, denitrification rates were much higher in the upper-basin compared to down basin. In swamp forests, values as high as 1590 and $1488 \mu \mathrm{mol} \mathrm{m}{ }^{-2} \mathrm{~h}^{-1}$ were reported. In Bayou Chevreuil peak values were 413 to $895 \mu \mathrm{mol} \mathrm{m}{ }^{-2} \mathrm{~h}^{-1}$ while in Lac des Allemands the highest value was $1376 \mu \mathrm{mol} \mathrm{m}^{-2} \mathrm{~h}^{-1}$. The Lake Cataouatche peak value was $280 \mu \mathrm{mol} \mathrm{m}{ }^{-2} \mathrm{~h}^{-1}$ while for the Davis Pond diversion it was $678 \mu \mathrm{mol} \mathrm{m}{ }^{-2} \mathrm{~h}^{-1}$. Clearly, the submerged sediments and wetland soils of the basin have very high potential denitrification rates.

\section{Conclusions}

In summary, the Barataria Basin is characterized by an upper-basin with high turbidity, nutrients and chlorophyll $a$ levels, and a mid- and lower-basin with clearer water and low nutrients and 
chlorophyll $a$ concentrations. The biggest change in the basin was at Lake Cataouatche, which became clearer and less eutrophic with addition of river water that had passed through a large wetland area before entering the lake. In general, the trophic status of the basin has remained relatively unchanged, with a eutrophic upper-basin and a lower-basin that has remained more mesotrophic without significant water quality deterioration.

Supplementary Materials: The following are available online at http://www.mdpi.com/2073-4441/12/11/3143/s1, Figure S1. Station locations used by [16,24] for quarterly transects of the Barataria Basin in 1977-1978; Figure S2. Station locations used by [23] for monthly transection in the Barataria Basin in 1994-2016. Additional stations in eastern Lake Salvador and Lake Cataouatche were added in 2005 to reflect the impact of the Davis Pond Diversion; Table S1. Station groupings used for comparisons of Seaton and Turner (Pre- and Post-diversion) transects; Table S2. ANOVA Results for the interaction effect, pairwise comparisons of the three time periods (Pre-diversion, Post-diversion, Seaton) across the ten stations. Significance is denoted as follows: “***” strongly significant at the Bonferroni protected 0.05; " "**" moderately significant at the Bonferroni protected 0.10; “*” weakly significant at unprotected Fisher's least significant difference 0.05 ; “NS" non-significant.

Author Contributions: Conceptualization, J.W.D., B.L., and B.D.M.; methodology, B.L., B.D.M.; software, B.D.M., B.L. and D.Z.; validation, B.D.M., B.L. and D.Z.; formal analysis, B.L., B.D.M., and J.W.D.; investigation, J.W.D., B.L., B.D.M. and R.R.L.; resources, J.W.D.; data curation, B.L. and B.D.M.; writing-original draft preparation, J.W.D., B.D.M. and R.R.L.; writing-review and editing, R.R.L., J.W.D., B.D.M., B.L., and D.Z.; visualization, J.W.D.; supervision, J.D.W.; project administration, J.D.W.; funding acquisition, none. All authors have read and agreed to the published version of the manuscript.

Funding: This research received no external funding.

Acknowledgments: We thank Eugene Turner and colleagues for making their extensive data set available.

Conflicts of Interest: The authors declare no conflict of interest.

\section{References}

1. Batker, D.; de la Torre, I.; Costanza, R.; Day, J.; Swedeen, P.; Boumans, R.; Bagstad, K. The threats to the value of ecosystem goods and services of the Mississippi delta. In Perspectives on the Restoration of the Mississippi Delta; Day, J., Kemp, P., Freeman, A., Muth, D., Eds.; Springer: New York, NY, USA, 2014; pp. 155-174.

2. Roberts, H.H. Dynamic changes of the holocene Mississippi River delta plain: The delta cycle. J. Coast. Res. 1997, 13, 605-627.

3. Blum, M.D.; Roberts, H.H. The Mississippi delta region: Past, present, and future. Annu. Rev. Earth Planet. Sci. 2012, 40, 655-683. [CrossRef]

4. Hijma, M.; Shen, Z.; Toörnqvist, T.; Mauz, B. Late Holocene evolution of a coupled, mud-dominated delta plain-chenier plain systems, coastal Louisiana, USA. Earth Surf. Dynam. 2018, 5, 689-710. [CrossRef]

5. Britsch, L.D.; Dunbar, J.B. Land loss rates: Louisiana coastal plain. J. Coast. Res. 1993, 9, 324-338.

6. Couvillion, B.R.; Beck, H.; Schoolmaster, D.; Fischer, M. Land area change in coastal Louisiana 1932 to 2016. U.S. Geol. Surv. Sci. Investig. Map 2017, 3381, 16p. [CrossRef]

7. Day, J.W.; Britsch, L.D.; Hawes, S.; Shaffer, G.; Reed, D.J.; Cahoon, D. Pattern and process of land loss in the Mississippi Delta: A spatial and temporal analysis of wetland habitat change. Estuaries 2000, 23, 425-438. [CrossRef]

8. Day, J.W.; Boesch, D.F.; Clairain, E.J.; Kemp, G.P.; Laska, S.B.; Mitsch, W.J.; Orth, K.; Mashriqui, H.; Reed, D.J.; Shabman, L.; et al. Restoration of the Mississippi delta: Lessons from hurricanes Katrina and Rita. Science 2007, 315, 1679-1684. [CrossRef]

9. Day, J.; Shaffer, G.; Cahoon, D.; DeLaune, R. Canals, backfilling and wetland loss in the Mississippi Delta. Estuar. Coast. Shelf Sci. 2019, 227. [CrossRef]

10. Day, J.W.; Clark, H.C.; Chang, C.; Hunter, R.; Norman, C.R. Life cycle of oil and gas fields in the Mississippi River Delta: A Review. Water 2020, 12, 1492. [CrossRef]

11. Southwick, L.M.; Grigg, B.C.; Kornecki, T.S.; Fousse, J.L. Potential influence of sugarcane cultivation on estuarine water quality of Louisiana's gulf coast. J. Agric. Food Chem. 2002, 50, 4393-4399. [CrossRef]

12. Yu, K.; DeLaune, R.; Tao, R.; Beine, R. Nonpoint source of nutrients and herbicides associated with sugarcane production and its impact on Louisiana coastal water quality. J. Environ. Qual. 2008, 37, 2275-2283. [CrossRef] 
13. Bricker, S.; Longstaff, B.; Dennison, W.; Jones, A.; Boicourt, K.; Wicks, C.; Woerner, J. Effects of Nutrient Enrichment in the Nation's Estuaries: A Decade of Change. In NOAA Coastal Ocean Program Decision Analysis Series No. 26; National Centers for Coastal Ocean Science: Silver Spring, MD, USA, 2007; p. 328.

14. NRC-National Research Council. Clean Coastal Waters: Understanding and Reducing the Effects of Nutrient Pollution; National Academy Press: Washington, DC, USA, 2000.

15. Zingone, A.; Phlips, E.J.; Harrison, P.J. Multiscale variability of twenty-two coastal phytoplankton time series: A global scale comparison. Estuaries Coasts 2010, 33, 224-229. [CrossRef]

16. Seaton, A.; Day, J. The development of a trophic state index for the quantification of eutrophication in the Barataria Basin. In Proceedings of the Third Marsh and Estuary Management Symposium, Louisiana State University, Division of Continuing Education, Baton Rouge, LA, USA, 25-29 March 1979; pp. 113-125.

17. Hopkinson, C.S.; Day, J.W. Modeling hydrology and eutrophication in a Louisiana swamp forest ecosystem. Environ. Manag. 1980, 4, 325-335. [CrossRef]

18. Hopkinson, C.S.; Day, J.W. Modeling the relationship between development and storm water and nutrient runoff. Environ. Manag. 1980, 4, 315-324. [CrossRef]

19. Day, J.; Hopkinson, C.; Conner, W. An analysis of environmental factors regulating community metabolism and fisheries production in a Louisiana estuary. In Estuarine Comparisons; Kennedy, V., Ed.; Academic Press: New York, NY, USA, 1982; pp. 121-136.

20. Kemp, P.; Day, J. Nutrient dynamics in a swamp receiving agricultural runoff. In Cypress Swamps; Ewel, K., Odum, H.T., Eds.; U. Fla Press: Gainesville, FL, USA, 1984; pp. 286-293.

21. Day, J.; Kemp, P. Long term impacts of agricultural runoff in a Louisiana swamp forest. In Ecological Considerations in Wetlands Treatment of Municipal Waste Water; Godfrey, P., Ed.; Van Norstrand Reinhold Co.: New York, NY, USA, 1985; pp. 317-326.

22. Lane, R.R.; Huang, H.; Day, J.W.; Justic, D.; DeLaune, R.D. Water quality of a coastal Louisiana swamp and how dredging is undermining restoration efforts. Estuar. Coast. Shelf Sci. 2015, 152, 23-32. [CrossRef]

23. Turner, R.; Swenson, E.; Milan, C.; Lee, J. Spatial variations in chlorophyll a, C, N, and P in a Louisiana estuary from 1994 to 2016. Hydrobiologia 2019, 834, 131-144. [CrossRef]

24. Seaton, A. Nutrient Chemistry in the Barataria Basin-A Multivariant Approach. Master's Thesis, Louisiana State University, Baton Rouge, LA, USA, 1979; 123p.

25. Hopkinson, C.; Day, J.; Kjerfve, B. Ecological significance of summer storms on shallow coastal lake and estuarine systems. Contrib. Mar. Sci. 1985, 28, 69-77.

26. Wiseman, W.J., Jr.; Swenson, E.M.; Power, J. Salinity trends in Louisiana estuaries. Estuaries 1990, 13, $265-271$. [CrossRef]

27. Wissel, B.; Gace, A.; Fry, B. Tracing river influences on phytoplankton dynamics in two Louisiana estuaries. Ecology 2005, 86, 2751-2762. [CrossRef]

28. Britsch, L.D.; Dunbar, J.B. Land Loss in Coastal Louisiana 1932 to 2001. In A Series of 7 Large Format Maps; Technical Report ERDC/GSL TR-05-13; Engineer Research and Development Center: Vicksburg, MS, USA, 2006.

29. Condrey, R.E.; Hoffman, P.E.; Evers, D.E. The last naturally active delta complexes of the Mississippi River (LNDM): Discovery and implications. In Perspectives on the Restoration of the Mississippi Delta; Day, J.W., Kemp, G.P., Freemen, A.M., Muth, D.P., Eds.; Springer: Dordrecht, The Netherlands, 2014; pp. 33-50.

30. Day, J.W.; Cable, J.E.; Lane, R.R.; Kemp, G.P. Sediment deposition at the Caernarvon crevasse during the great Mississippi Flood of 1927: Implications for coastal restoration. Water 2016, 3, 38. [CrossRef]

31. Kaufman, L.; Rousseeuw, P. Finding Groups in Data: An Introduction to Cluster Analysis; Wiley: New York, NY, USA, 1990; 368p.

32. Brezonik, P.; Shannon, E. Trophic state of lakes in north central Florida. In Florida Water Resources Research Center; Publ. No. 13; University of Florida: Gainesville, FL, USA, 1971.

33. DeLaune, R.D.; Jugsujinda, A.; West, J.L.; Johnson, C.B.; Kongchum, M. A screening of the capacity of Louisiana freshwater wetlands to process nitrate in diverted Mississippi River water. Ecol. Eng. 2005, 25, 315-321. [CrossRef]

34. Rivera-Monroy, V.; Lenaker, P.; Twilley, R.; DeLaune, R.; Lindau, C.; Nuttle, W.; Habib, E.; Fulweiler, R.; Castaneda-Moya, E. Denitrification in coastal Louisiana: A spatial assessment and research needs. J. Sea Res. 2010, 63, 157-172. [CrossRef]

35. Swenson, E.; Turner, R.E. Past, Present, and Probable Future Salinity Variations in Barataria Estuarine System; Louisiana State University-Coastal Ecology Institute: Baton Rouge, LA, USA, 1998. 
36. DeLaune, R.; Yu, K.; Devai, I.; Tao, I.R. Water Quality of Upper Barataria Basin: Impact of Nonpoint Source Pollution Associated with Sugarcane Production (St. James Sugarcane Run-off Project); Final Report DEQ Contract No. CFMS597, Grant number C9-996102-08; Louisiana State University: Baton Rouge, LA, USA, 2007; 104p.

Publisher's Note: MDPI stays neutral with regard to jurisdictional claims in published maps and institutional affiliations.

(C) 2020 by the authors. Licensee MDPI, Basel, Switzerland. This article is an open access article distributed under the terms and conditions of the Creative Commons Attribution (CC BY) license (http://creativecommons.org/licenses/by/4.0/). 